\title{
The complex history of Pueblo Bonito and its interpretation
}

\author{
Patricia L. Crown ${ }^{1, *} \&$ W.H. Wills ${ }^{1}$
}

Pueblo Bonito in Chaco Canyon is one of the most iconic pre-Hispanic archaeological sites in the U.S. Southwest. Archaeologists refer to it as a great house in recognition of its massive scale, and often describe it as the centre of the Chaco world. Yet questions remain about Pueblo Bonito's origins, sequence of construction, duration of occupation and abandonment. Here, the authors present new research that helps to clarify the early phases of occupation, and illuminates some of the problems inherent in reconstructing a building that was a perennial work in progress.

Keywords: Chaco Canyon, Pueblo Bonito, Ancestral Pueblo, construction sequence, architecture

Pueblo Bonito (Figure 1) is arguably among the most important archaeological sites in the U.S. Southwest. Yet despite over a century of research, its origins, construction sequence, size, occupants, function and abandonment remain topics of debate (see Vivian 1990; Mills 2002; Neitzel 2003; Lekson 2006, 2007; Heitman \& Plog 2015). Why are archaeologists unable to reach consensus on Pueblo Bonito? Here we propose that the site confounds interpretation due both to its excavation history and the fact that its inhabitants settled into a never-ending project of construction, remodelling, renewal and destruction (Figure 2). In this article, we review the origins, construction sequence and abandonment of Pueblo Bonito. This builds on earlier research highlighting evidence for frequent renewal projects at the site (Crown \& Wills 2003), and incorporates new data from our 14 years of excavation and analysis. We conclude that the history of this great house may never be fully understood—in part because its builders never considered it to be finished.

\section{Background to understanding Pueblo Bonito}

Pueblo Bonito is located in Chaco Canyon in north-western New Mexico, at an elevation of approximately $1890 \mathrm{~m}$ asl. Average modern annual precipitation is around $225 \mathrm{~mm}$, with record minimum and maximum temperatures ranging from -34 to $38^{\circ} \mathrm{C}$. The canyon is cut through Cretaceous sandstones, forming vertical cliffs on the north and south margins of the floodplain, which is $0.75 \mathrm{~km}$ wide at Pueblo Bonito. The valley floor is dissected by the Chaco Arroyo, which has a complex history of aggradation and erosion; its current course formed in the nineteenth century AD (Wills et al. 2016).

1 Department of Anthropology, University of New Mexico, MSC01 1040, Albuquerque, NM 87131-1086, USA Author for correspondence (Email: pcrown@unm.edu) 


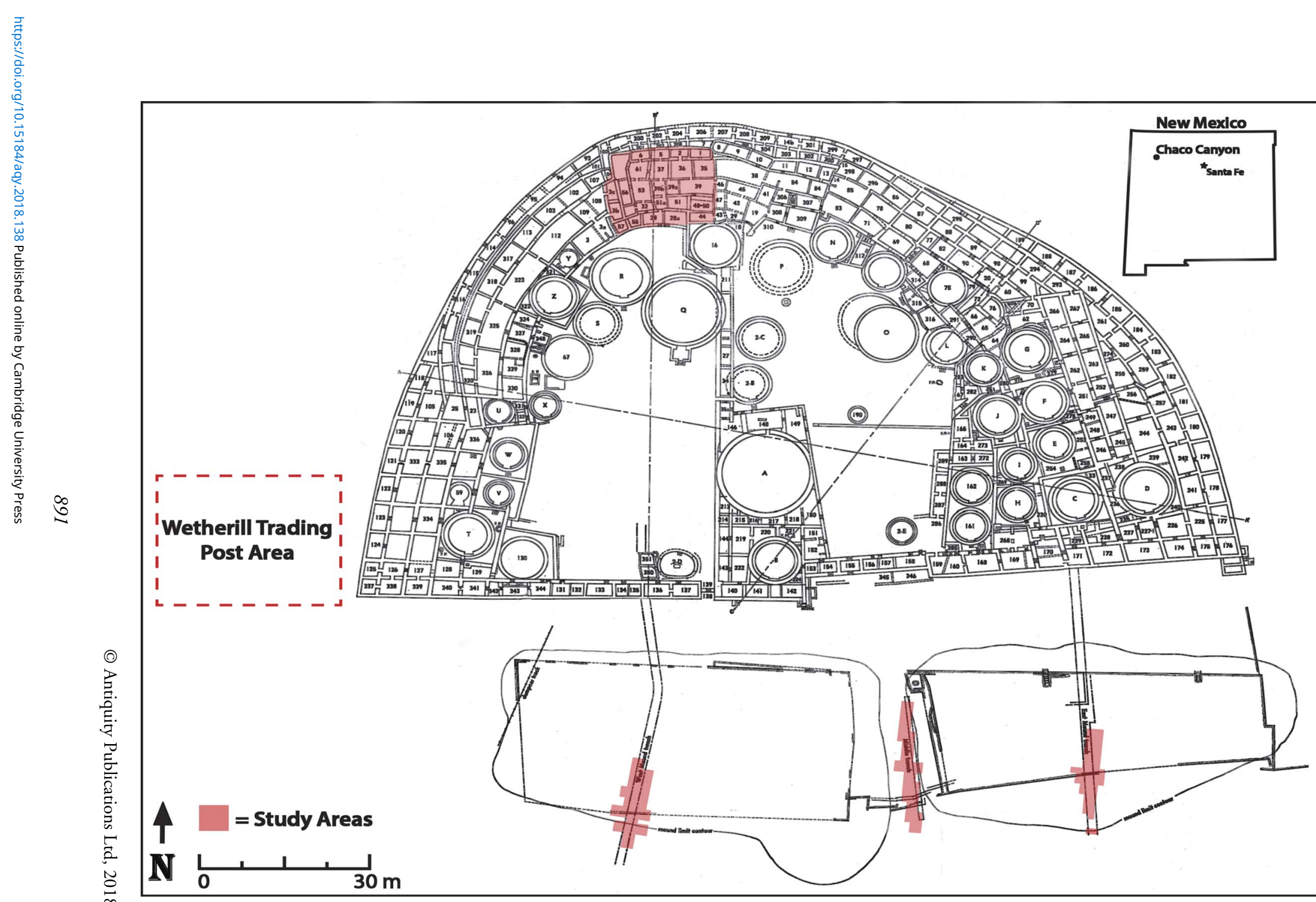

Figure 1. Map of Pueblo Bonito, highlighting areas of new excavation. Figure by Beau Murphy and Wetherbee Dorshow. 
Two major archaeological projects have excavated most of Pueblo Bonito. From 1896-1899, the Hyde Exploring Expedition excavated around 200 rooms, under the supervision of Richard Wetherill and George Pepper (Pepper 1909,

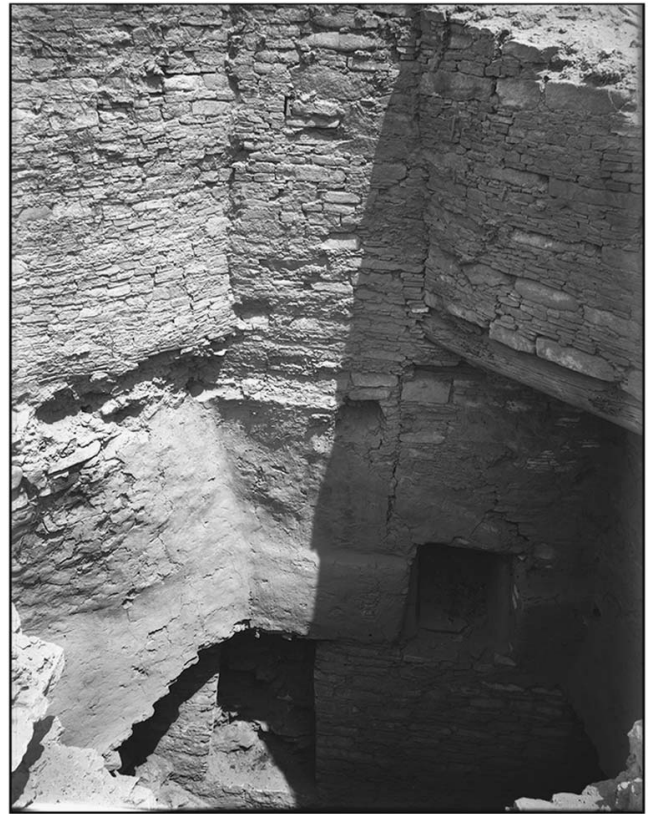

Figure 2. 1897 photograph of Room 70 in Pueblo Bonito, illustrating the complexity of the architectural sequence. Image \#411995, American Museum of Natural History Library.

for ritual activities. In the Chaco area, such sites are called 'great houses' to distinguish them from much smaller single-storey villages, which lack many of the features of the larger sites. Great houses are often described as 'monumental' in scale (Lekson 1984). Archaeologists date Pueblo Bonito based on stratigraphy, masonry styles, bonding/abutting of wall corners, ceramics, as well as tree-ring, radiocarbon and archaeomagnetic samples (see Windes 2003). There are, however, problems with all of these dating techniques. In particular, Chacoans reused wood from old structures when building new structures, refurbished older rooms with new pieces of wood and remodelled tirelessly. Reconstructing the sequence is critical for addressing important issues at Pueblo Bonito. These include whether the site represents a local development or a migration of populations from outside the canyon, how the site reflects changing architectural and societal constructions, and what socio-economic strategies were required to manage construction events.

\section{Origins: what lies beneath}

Pueblo Bonito was built on a location occupied during the Basketmaker III Period (c. AD 450-750), a period characterised by agricultural economies and the first ceramics in the northern U.S. Southwest. Basketmaker III-Period ceramics are present in small amounts at (C) Antiquity Publications Ltd, 2018 


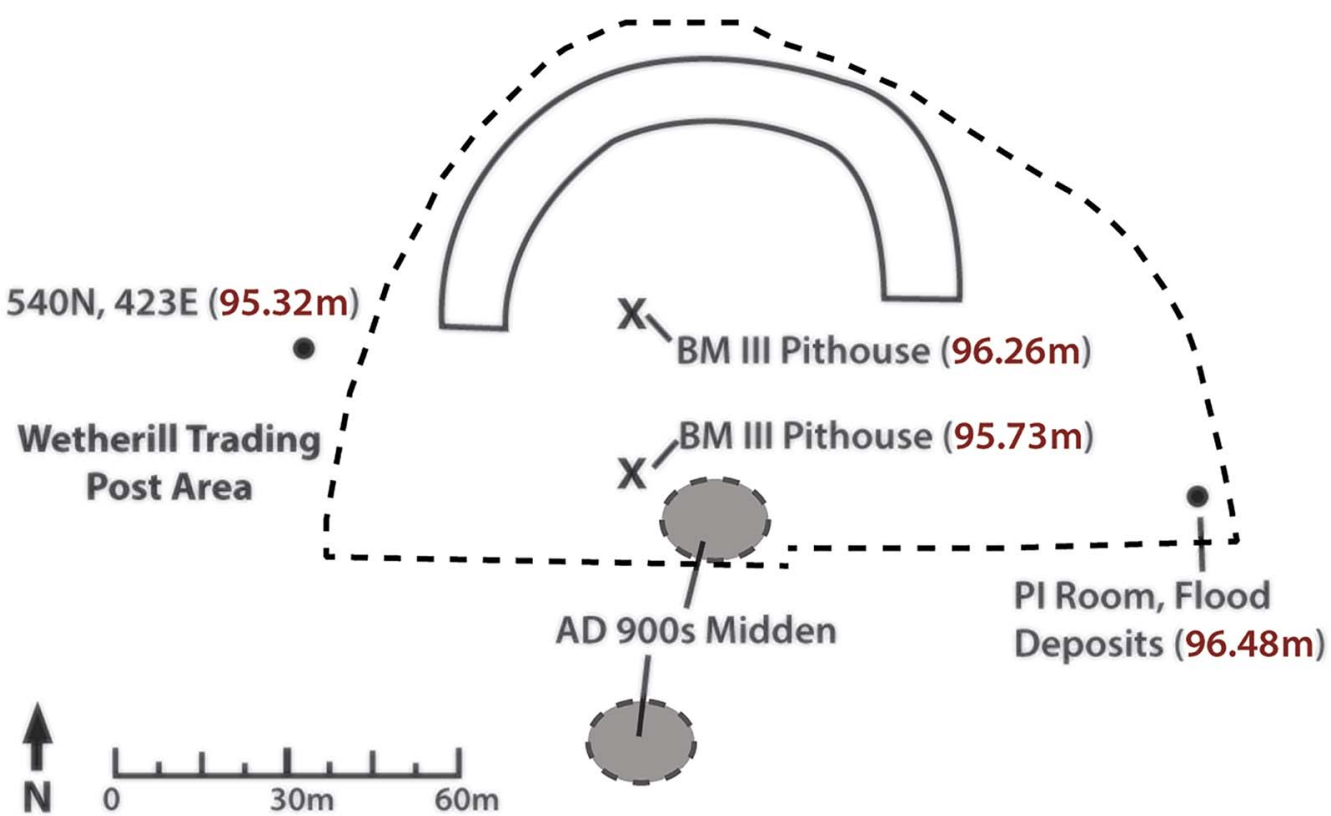

Figure 3. Location of deeply buried Basketmaker III-Period pithouses, Pueblo I structures, features, refuse accumulations and flood deposits relative to the architectural footprint at $A D 900$ (crescent shape) and $A D 1100$ (dashed line). The site datum elevation is $100 \mathrm{~m}$ and located on the West Mound (see Figure 1). Figure by Beau Murphy.

Pueblo Bonito, indicating occupation in the seventh and eighth centuries AD. Basketmaker III-Period settlements consisted of dispersed single-room pithouses, extramural storage bins and, in some cases, a large public structure called a great kiva. Basketmaker III-Period sites are common around Pueblo Bonito-especially opposite the great house on the south side of the canyon (Judd 1924; Dutton 1937; Kluckhohn 1939; McKenna \& Truell 1986; Wills \& Windes 1989; Wills et al. 2012; Windes 2014). At Pueblo Bonito, Judd (1964) encountered two pithouses under the West Court (Figure 3), around $4 \mathrm{~m}$ below the current surface. These appear to be Basketmaker III Period in date, at elevations consistent with radiocarbon-dated layers of mixed fluvial and cultural deposits documented in test units approximately $15 \mathrm{~m}$ west of the great house (discussed below).

Between c. $100 \mathrm{BC}$ and $\mathrm{AD} 1000$, the valley bottom in Chaco was a relatively flat, seasonally wet flood plain (Hall 2010: 236). Although pollen data do not indicate the presence of perennial wetlands in Chaco during this period, Bryan (1954: 51) suggests that marshy areas along the base of the north-side cliffs may have supported cattails and other riparian plants. Mesa-top runoff pours over the edge at a number of places on the north side of the canyon, creating temporary pools and small channels that flow onto the floodplain. Archaeological data suggest that this combination of convergent water sources was critical for farming during the Basketmaker III Period in Chaco (Wills et al. 2012)—including in the area where Pueblo Bonito would be built.

Tree-ring dates indicate that construction of Pueblo Bonito began in the ninth century $\mathrm{AD}$ and continued into the early tenth century, thus spanning the conventional temporal 


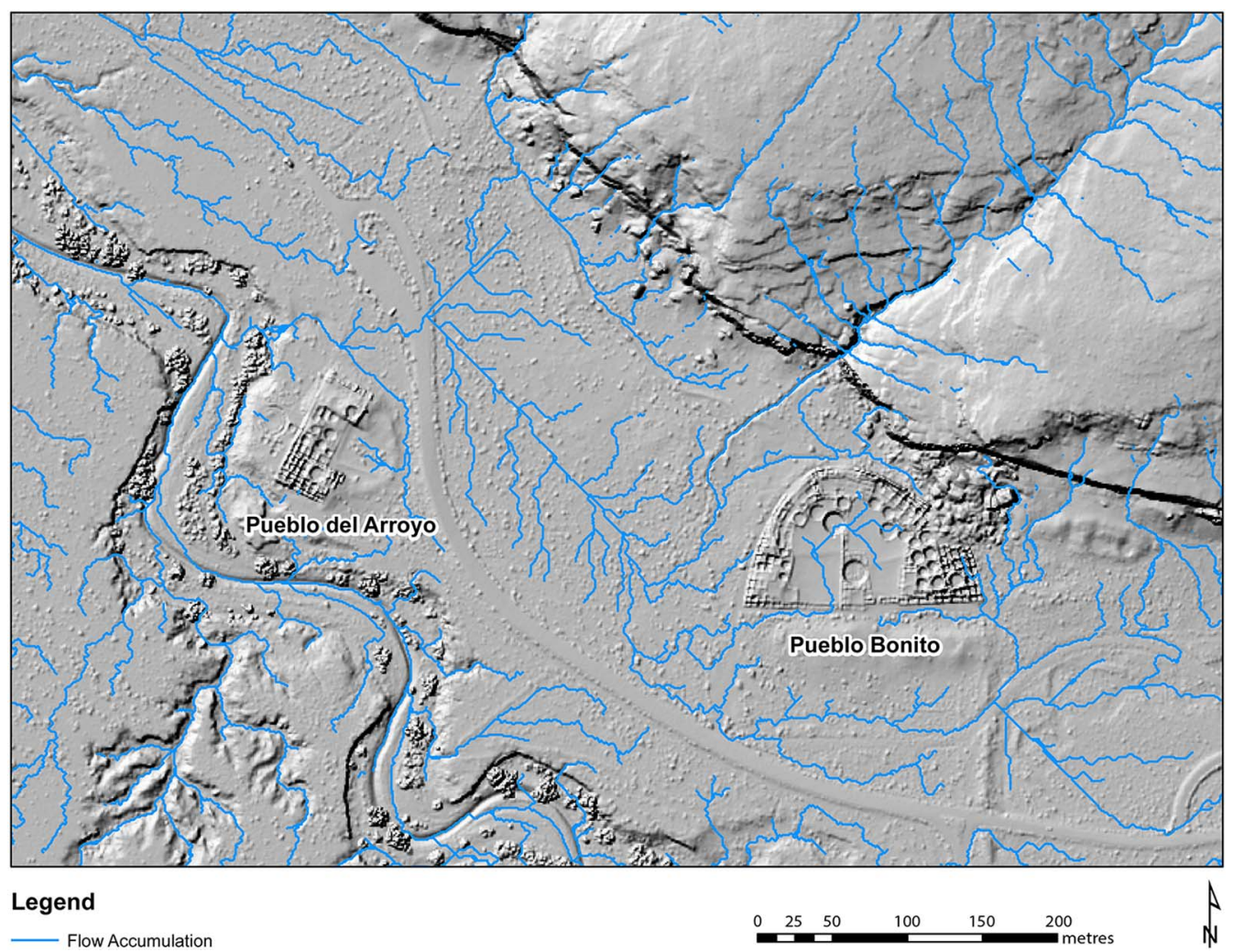

Figure 4. Modern surface water flow-accumulation model for the area around Pueblo Bonito. Terrain model constructed from LiDAR data (www.ncalm.org) by Joseph Birkman.

boundary between Pueblo I (c. AD 750-900) and Pueblo II (c. AD 900-1100). This was a dynamic cultural period in Chaco Canyon that saw the number of habitation sites double from the Basketmaker III Period. Windes (2014) has documented the appearance of distinct communities during this interval along the entire length of the canyon and adjacent tributaries. These were characterised by dispersed household structures surrounding a larger masonry building. Pueblo Bonito fits this pattern, particularly in having two large tenthcentury middens that were later buried by expansion of the pueblo (Figure 3). Wilshusen and Van Dyke (2006) believe that the canyon population during the ninth century AD was modest in size. Nonetheless, they acknowledge that Pueblo Bonito and other post-ninthcentury great houses probably obliterated or buried preceding settlements, making it difficult to estimate the size of earlier local populations.

Unlike the wide, shallow drainages outside Chaco, the canyon alluvial environment was aggrading between $\mathrm{AD} 800$ and 1000. Many late eighth- and ninth-century structures located on the valley floor, and exposed through excavation or erosion, are buried by flood deposits (Judd 1924; Adams 1951; Bryan 1954; Bradley 1971; Wills et al. 2012). Similar flooding may have affected the early occupation at Pueblo Bonito; the great house is located on deep sandy sediments at the base of a cliff-slightly higher than the adjacent floodplain today (Figure 4). Deep stratigraphic test pits below rooms in the south-east part of Pueblo Bonito and outside (C) Antiquity Publications Ltd, 2018 


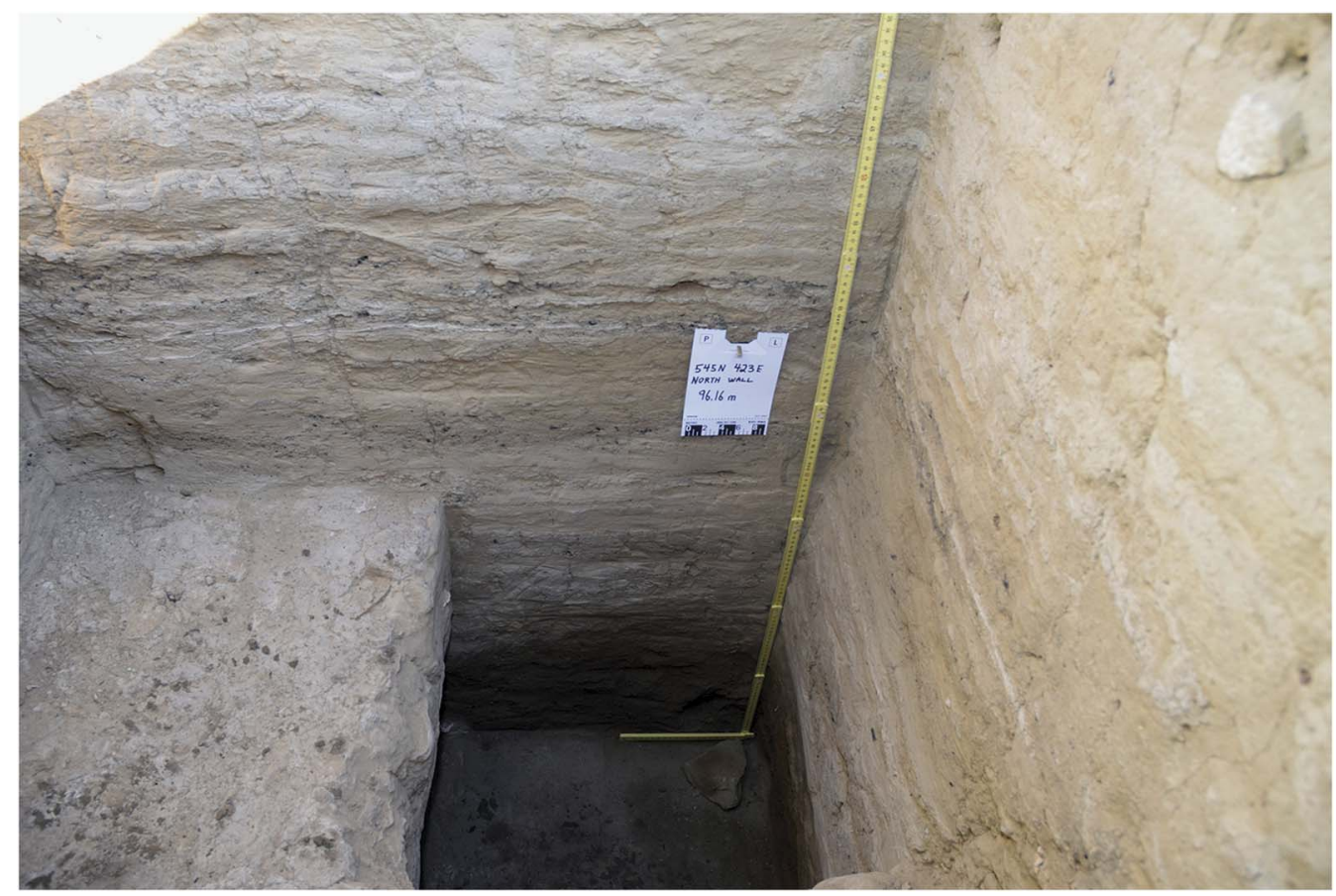

Figure 5. North profile of 545 north 423 east, in the Wetherill Trading Post area approximately $15 m$ west of Pueblo Bonito, showing alternating sand, silt-clay layers and charcoal-ash lenses. Charcoal from the base of the unit (95.31m, site datum is $100 \mathrm{~m})$ is dated at 551-636 cal AD; charcoal at $95.39 \mathrm{~m}$ is dated at 772-887 cal AD; charcoal at 96.12m is dated at 889-986 cal AD (respectively: samples AA109842, AA109843 and AA109841 (95.4\%, OxCal4.2/IntCal13, Bronk Ramsey 2009; Reimer et al. 2013)).

the western walls have encountered distinctive strata of water-lain silts interfaced with layers containing ash, charcoal and artefacts. More than two metres below the floor of Room 241, estimated to have been built between AD 1075 and 1085 (Lekson 1984), these deposits covered a floor surface and razed wall consistent with ninth-century building techniques (Judd 1964: 77). Three recently excavated test units located 10-20m west of Pueblo Bonito revealed alternating layers of sand and silt-clay layers mixed with cultural material. These layers sloped to the west (Figure 5), and formed as floodwaters receded and became less turbulent. These data indicate that seasonal floods extended over some parts of ninth-century Pueblo Bonito.

It has been suggested that construction of Pueblo Bonito began abruptly because the first distinctive architectural units seem to appear fully formed and without precedent (Wilshusen \& Van Dyke 2006). Windes and Van Dyke (2012: 100) suggest that migrants from the San Juan River area, approximately $190 \mathrm{~km}$ north of Chaco, were responsible for this initial construction based on similarities in architecture. There is, however, currently no independent archaeological evidence-such as ceramic patterning or biochemical data- that supports an influx of northern populations in the ninth century AD (see Kantner 2012; Price et al. 2017; Mills et al. 2018).

Furthermore, recent excavations in the north-central part of the building, combined with archival materials, provide new information suggesting that the earliest settlement might

(C) Antiquity Publications Ltd, 2018 
have been larger than previously assumed, both in terms of the number of rooms and population size. The earliest rooms in this northern area had masonry walls, and may have been of the architectural form called 'tub'

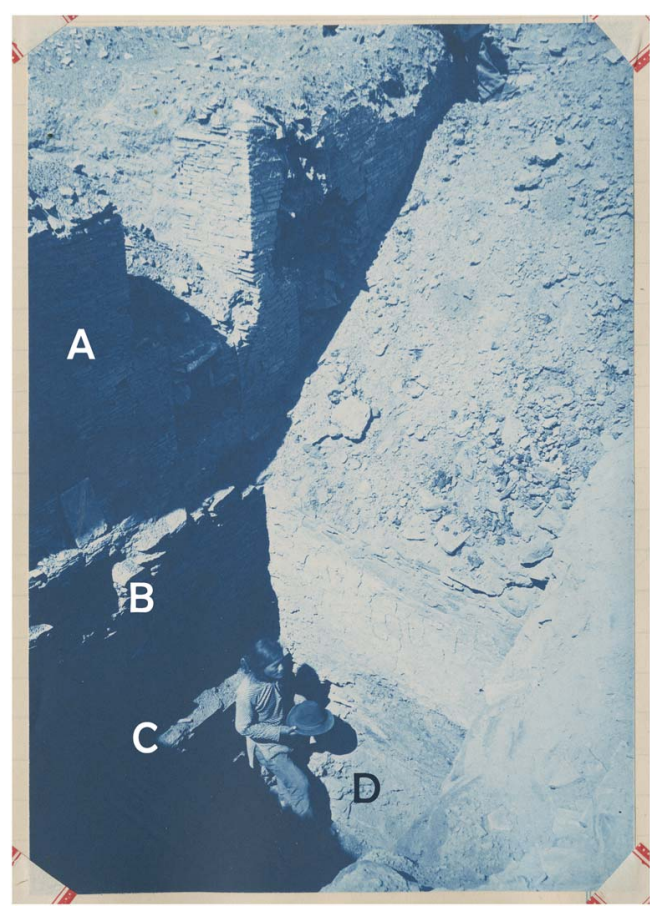

Figure 6. 1897 photograph of excavations in Room 28a: A) upper-storey wall constructed c. $A D$ 1071;

$B)$ lower-story wall constructed c. AD 850-925;

C) lower-storey floor; D) shelf-like projections of probable tub room. The workman stands on the tub room floor. The sloping backfill sits in Room 28 to the west. Catalogue \# Hyde Exploring Expedition 184. Courtesy of the Division of Anthropology, American Museum of Natural History. rooms, which may be restricted to the San Juan Basin (Windes 1993). Tub rooms had square to rounded masonry walls with floors that included a central, bathtub-shaped depression 200-400 $\mathrm{mm}$ deep, surrounded by shelves $150-250 \mathrm{~mm}$ wide (Windes 1993). Pueblo Bonito rooms believed to date to the late $\mathrm{AD} 800$ s or early 900 s (Windes 2003) have possible tub rooms underlying them. Pepper (1920: 126-28), for example, found two floors in Room 28a, at depths of $1.83 \mathrm{~m}$ and $2.59 \mathrm{~m}$ below the ceiling level of the room. The higher floor corresponds to the depth of the floor we located in adjacent Room 28, but the lower floor was excavated $0.3 \mathrm{~m}$ into sterile sand. A photograph of the room (Figure 6) shows shelf projections around the workman standing on the lower floor, supporting the idea that this was a tub room. Immediately to the south of this room and at approximately the same elevation, Judd (1964: 76-77) found the possible remains of a second tub room. Based on stratigraphy and depth, two additional rooms found under Room 56 are probably contemporaneous (Figure 7; Pepper 1920).

Given the probable chronology of the rooms above these subfloor features, these earlier rooms must date to the $\mathrm{AD} 800$ s—and probably the early 800s—dates supported by ceramics from adjacent surfaces. Tub rooms usually have adjacent ramadas (roofed shelters without walls; Windes 1993: fig. 4.1), which may explain the concentration of postholes found in late nineteenth-century Hyde Exploring Expedition excavations of later masonry rooms located adjacent to the probable tub rooms (Figure 7). Thus, some of the postholes shown in Figure 7 may have served to support ramadas adjoining the tub rooms and then been incorporated into the later room construction. Strata beneath the Room 28 floor that are probably contemporaneous with the structure under Room 28a contain large numbers of turkey gastroliths, suggesting that turkeys were kept there. In other sites in Chaco with tub rooms, the rooms are situated west or north of pithouses (see also Wilshusen \& Van Dyke 2006). Unfortunately, any pit structures located south or east of Room 28 a would have been disturbed by the later construction in the West Court. Other parts of Pueblo Bonito have structures beneath what are generally considered the earliest rooms at the site (including a (C) Antiquity Publications Ltd, 2018 


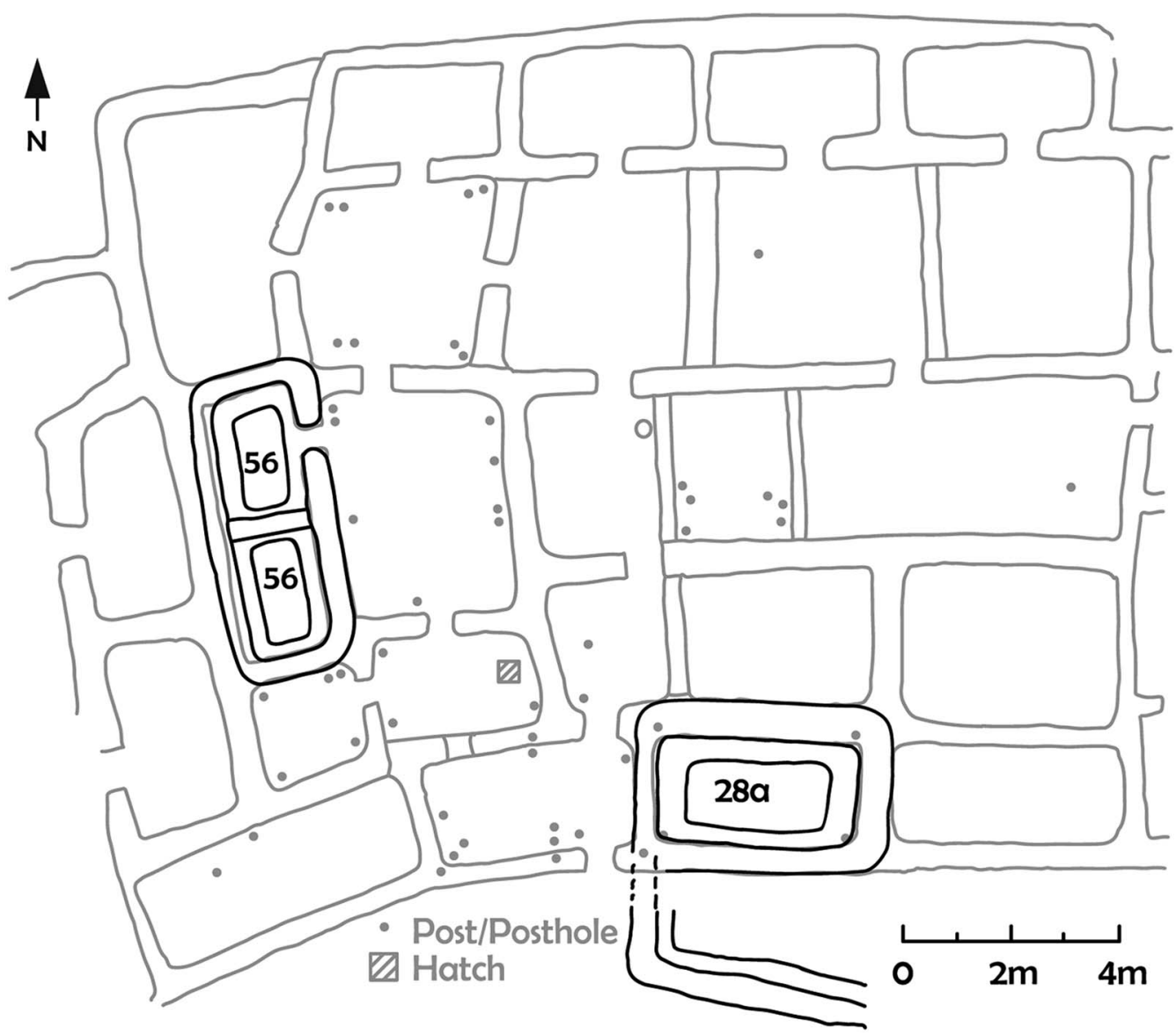

Figure 7. Possible tub rooms in black, with later rooms and known postholes in grey. Figure by Drew Wills.

probable kiva under the ground floor of Room 83 (Pepper 1920), along with the room found deeply buried beneath Room 241, mentioned above).

Between c. AD 850 and 925, the inhabitants of Pueblo Bonito constructed masonry rooms that varied from one to four storeys in height and used diverse construction methods (Figure 8). These include: the use of large sandstone blocks, with little evidence of mortar; smaller, tabular pieces of sandstone laid closely without defined rows; jacal (wattle-anddaub); and stone courses widely spaced by large quantities of mud. Importantly, exhausted grinding stones incorporated into the masonry walls support the idea of an extensive local settlement prior to the construction of these rooms. Rooms fronting the plazas (including Rooms 28, 323, 325 and 326; Judd 1964) had many postholes situated primarily on the plaza side of the room. These plaza-side postholes had cones of adobe at the base that sloped gradually downwards to the floor. These may have initially supported a ramada, with the room walls added later. The high concentration of posts in some masonry rooms (e.g. Rooms $28,32,33,53,61)$ contrasts with rooms with no posts. This may provide evidence that ramadas or jacal-walled rooms preceded the masonry rooms. Indeed, the largely linear nature of the rooms with posts suggests that the area from Rooms 28-61 might have consisted of 


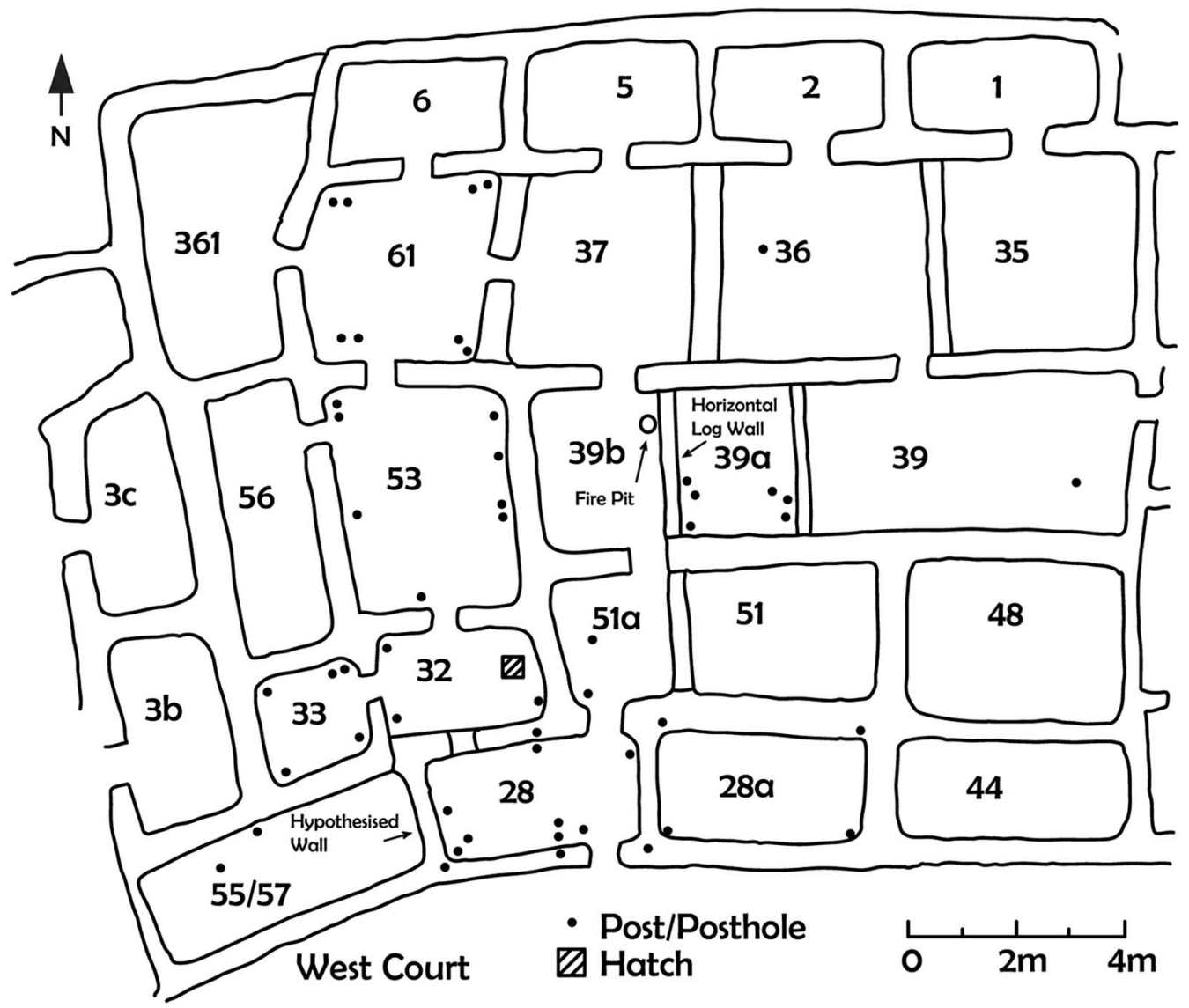

Figure 8. Ground-floor rooms in the north-central part of Pueblo Bonito, probably constructed in the interval from c. AD 850-925. Figure by Drew Wills.

jacal rooms fronting small masonry storage rooms (e.g. Room 33 and the two rooms under Room 56) with a courtyard to the east. Later construction then shifted the 'front' of this part of Pueblo Bonito from east- to south-facing.

The diverse wall-construction techniques indicate a lack of a unified architectural style in this early period. This may suggest construction by individual households using their own building methods, a lack of architectural specialists, or such widely spaced construction episodes that individuals lacked continuity in ways of building. Whatever the reasons, the early architecture of Pueblo Bonito shows a great deal of variation. One favoured building method that emerged during this time was the construction of a long narrow room that was divided with interior walls. In the northern area, Rooms 35, 36, 37, 39, 39a, 39b and 61 show this pattern, with interior cross walls comprising masonry, horizontal logs, or a combination of jacal and masonry (Pepper 1920). These interior walls could be destroyed and moved as needs changed. Small rooms constructed behind these large rooms are usually assumed to be for storage (Vivian 1990). As shown in Figure 8, the rooms fronting the West Court probably constituted three separate single-storey rooms, each with straight walls, but placed slightly askew to create a curve.

(C) Antiquity Publications Ltd, 2018 
By the mid tenth century, this northern portion of Pueblo Bonito had approximately 25 ground-floor rooms. Burials recovered in Rooms 33 and 56 show that these rooms were eventually used as burial crypts. Initially, however, the other rooms appear to have served as domestic spaces, including as use for habitation, cooking and storage. Our excavations in Room 28 , for example, revealed several shallow, amorphous pits dug into the sand floor that served as thermal features. While formal hearths are relatively rare in Pueblo Bonito rooms, less formal features might have served for heating and cooking. This may confound attempts to estimate population levels based on the number of hearths (Windes 1984; Bernardini 1999). Pollen samples taken from a surface immediately beneath the floor and associated with the construction of Room 28 contain copious amounts of cattail pollen (Smith forthcoming), supporting the possible contemporaneous presence of a marshy area near the village.

Tree-ring dates indicate a hiatus in building activity throughout Pueblo Bonito between c. AD 975 and 1040. People may have abandoned part or all of the site during this interval. Although occupation of the existing rooms (without new construction) may have continued, areas of the village were "left unmaintained and then partly collapsed before new construction in the A.D. 1040s" (Windes \& Ford 1996: 301). Remodelling was such a continuous process at Pueblo Bonito that the absence of dates in this interval is striking.

When construction resumed in the northern rooms in the AD 1000s, the surface of the West Court had risen so much that it was approximately level with the roofs of the first-storey rooms. Judd (1964: 60) suggested that wind-blown sand contributed to this. Sand also piled up against the rear rooms, and new rooms were built on the accumulated sand (Lekson 1984: 133). While Judd saw these deposits as natural accumulation, Stein et al. (2003: 50) argued that occupants of Pueblo Bonito raised the surface level artificially. It is possible that the deposits represent both natural and cultural accumulation, particularly as excavation of large kivas may have deposited material around them. In the case of Room 28, which had a door leading to the West Court, the higher ground surface would have made this entrance inaccessible.

The eleventh century was a time of intensified building activities and remodelling at Pueblo Bonito. Tree-ring dates suggest construction of at least 80 new rooms at the rear of the pueblo from $\mathrm{AD} 1040-1050$. Another 24 rooms were built between $\mathrm{AD} 1050$ and 1070, and perhaps another 160-170 rooms between AD 1070 and 1100 (Windes \& Ford 1996: 302-303). Remodelling activities in the northern area included the replacement of Room 28 's north wall, the foundation clay for which sits on the floor level of the earlier room. The wall exhibits Type II masonry-a style believed to characterise the time between AD 1020 and 1060 .

Within a few decades, a new wall was added on the West Court side of the entire set of rooms from Room 28a to Room 57 at the same time that a second storey was added onto this arc of rooms (Figure 9). The new south wall for these rooms was two storeys high along the northern part of the West Court and set onto a foundation $0.53 \mathrm{~m}$ high. It must have been constructed by digging out the accumulated wind-blown sand deposits and placing the wall parallel to and just south of the existing north wall. The wall arc has a smaller diameter than the room walls it parallels, touching the wall of Room 28 but then curving away from the walls of the surrounding rooms to an ever greater extent. Figure 6 shows this upper wall creating a bench adjacent to Room 28a. The lower-storey ceiling sat on this bench. Tree-ring 


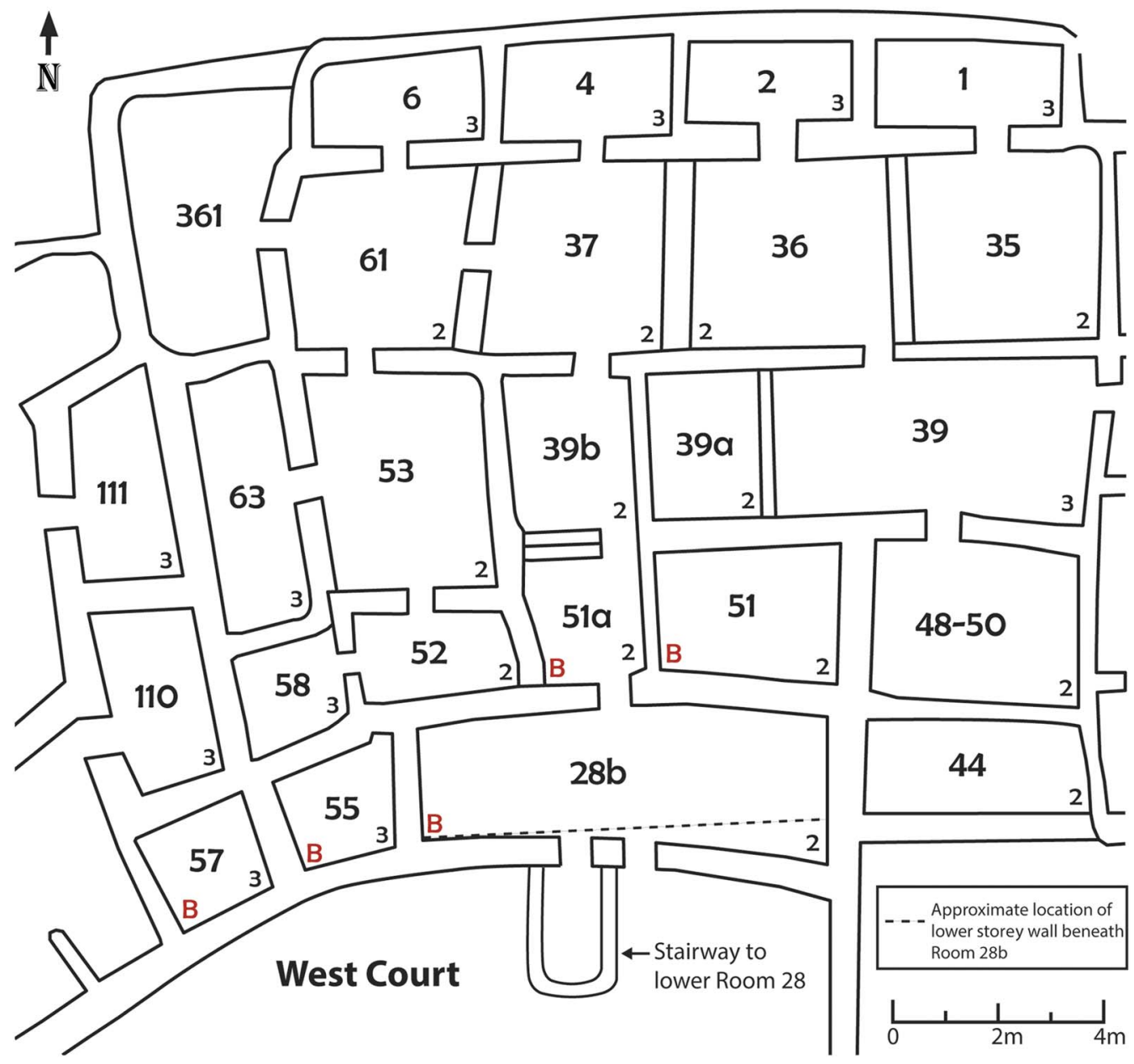

Figure 9. Configuration of north-central rooms after addition of a new wall on the northern side of the West Court. Small numbers in the right-hand corners are numbers of stories, based on Pepper (1920) and Judd (1964). Red 'B' indicates burned rooms. Figure by Beau Murphy.

dates from the new upper-storey rooms suggest construction in $\mathrm{AD} 1071$ - a date congruent with the Type IV masonry style (Lekson 1984: 19). New upper-storey Room 28b covered both lower Rooms 28 and 28a, and was fitted with two side-by-side T-shaped doorways. This unique configuration may have been important for ceremonial processions into the West Court (Crown 2018). A stairway framed inside masonry/mud walls was constructed from the West Court down to lower Room 28 (Judd 1954: 27), permitting individuals to enter and leave the now-underground set of rooms shown in Figure 8.

These underground rooms in the northern portion of Pueblo Bonito continued to be used, probably primarily for storage. A number of them were found to contain quantities of objects interpreted as being of ritual use (Neitzel 2007: 139), and perhaps owned by ritual or kin groups. In Room 28, for example, a room-wide wooden shelf was added at the time the northern wall was constructed. Pottery was stored here, particularly cylinder jars used in cacao-drinking ceremonies (Crown \& Hurst 2009; Crown 2012).

(C) Antiquity Publications Ltd, 2018 
Around AD 1100, the north-west door between Rooms 28 and 32 was sealed with masonry. Within Room 28, 173 ceramic vessels, including 112 cylinder jars, were placed on shelving, in groups blocking the doors, and on the upper room's floor. This constitutes the largest group of whole vessels recovered from any single room in the region. A fire was set around one of the posts on the lower floor, starting a conflagration that partially vitrified the sand floor and burned until the upper room collapsed and smothered the fire. Similar fires destroyed the adjacent rooms along the northern arc of the West Court (Figure 9). These were probably part of termination or retirement rituals, which closed the rooms from further use and removed the power from objects accorded animacy as spiritual beings (Mills 2008: 103; Mills \& Ferguson 2008; Crown 2018). It is possible that another depopulation prompted this termination at Pueblo Bonito. Sometime after these rooms burned, debris was pushed into the rooms and levelled. New plastered floors were placed over the debris, and a new partition wall was placed between Rooms 28 and 55. It is unclear whether Room 28b was ever re-roofed; evidence suggests it may have been used as a turkey pen. We cannot yet date the reuse of Room $28 \mathrm{~b}$ more precisely.

The presence of ceramics, including from the lower northern rooms, suggest continued occupation of Pueblo Bonito into the AD 1200s-perhaps by migrants from the Mesa Verde area to the north. Changes in ceramic type, architecture and refuse-disposal areas suggest that people with different practices occupied at least parts of the pueblo (Wills 2009). Fewer construction events indicate a focus on renovating ritual structures and the late construction of semi-subterranean houses scattered along the edge of the plazas (Windes \& Ford 1996: 303). That construction also continued at other great houses in Chaco Canyon suggests there was a substantial population elsewhere in the canyon. Ancestral Puebloans probably abandoned Pueblo Bonito by the fourteenth century, although as Windes and Ford (1996: 297) emphasise, both Navajo and Europeans later used the buildings, at least periodically.

The poorly documented and, in some cases, unethical excavations at Pueblo Bonito compound issues associated with interpreting any complex construction and use history. One archaeologist, for example, employed to make a "typical collection in three weeks" (Moorehead 1906: 33), hired nine men and a wagon, and went to Chaco Canyon in 1897. He eventually shipped around 2000 artefacts back to the East Coast. This group tore down the upper-storey walls of four rooms to reach the lower rooms with intact roofs. They plundered burials, scattering the human skeletal remains across three rooms (Marden 2011: 205), and sherds from individual ceramic vessels across five rooms. It has taken over a century to document the extent of this one looting episode at Pueblo Bonito.

It may be impossible to overcome completely the interpretive limitations resulting from poorly executed and documented past excavations. Our investigations of the refuse mounds, Room 28 and the Wetherill Homestead that have employed new dating techniques and analytical methods, such as ground-penetrating radar (Sturm \& Crown 2015), nevertheless provide an enhanced understanding of the complex sub-surface deposits and the warren of still-intact rooms throughout the great house. In conjunction with prior research by many scholars, these results indicate that Pueblo Bonito was probably established on an extensive earlier settlement, and that its entire occupation was one of near-constant architectural change, interrupted only once by a probable temporary abandonment in the late AD 900s. Pueblo Bonito may always have been experienced as a work in progress. We suspect this dynamism reflects the volatility of rapid socio-political transformation in early farming societies.

(C) Antiquity Publications Ltd, 2018 


\section{Acknowledgements}

We thank Barbara Mills for inviting us to participate in this special section. Thanks to David Hurst Thomas, Barry Landua and Kendra Meyer of the American Museum of Natural History for their help in securing archival material. Patricia Crown directed the Room 28 excavations with funding from the National Endowment for the Humanities (RZ-51417-13) and the National Geographic Society (9276-13), and permitted by the National Park Service (ARPA Permit 13-CHCU-01). W.H. Wills directed the refuse-mound excavations with funding from the National Science Foundation (BCS-0408720) and National Geographic Society (7653-04). Both authors directed the Wetherill area excavations with funding from the University of New Mexico.

\section{References}

Adams, R.N. 1951. Half house: a pithouse in Chaco Canyon, New Mexico. Papers of the Michigan Academy of Science, Arts, and Letters 35: 273-95.

Bernardini, W. 1999. Reassessing the scale of social action at Pueblo Bonito, Chaco Canyon, New Mexico. Kiva 64: 447-70.

Bradley, Z.A. 1971. Site Bc 236, Chaco Canyon National Monument, New Mexico. Washington, D.C.: Division of Archeology and Historic Preservation, National Park Service.

Bronk Ramsey, C. 2009. Bayesian analysis of radiocarbon dates. Radiocarbon 51: 337-60. https://doi.org/10.1017/S0033822200033865

Bryan, K. 1954. The geology of Chaco Canyon, New Mexico, in relation to the life and remains of the prehistoric peoples of Pueblo Bonito (Smithsonian Institution Miscellaneous Collections 122(7)). Washington, D.C.: Smithsonian Institution.

Crown, P.L. 2012. Chocolate consumption and cuisine from Chaco to colonial New Mexico. El Palacio 117(4): 36-42.

- (ed.). 2016. The Pueblo Bonito mounds of Chaco Canyon: material culture and fauna. Albuquerque: University of New Mexico Press.

- 2018. Drinking performance and politics in Pueblo Bonito, Chaco Canyon. American Antiquity 83: 387-406. https://doi.org/10.1017/aaq.2018.12

Crown, P.L. \& W.J. Hurst. 2009. Cacao use in the pre-Hispanic American Southwest. Proceedings of the National Academy of Sciences of the USA 106: 2110-13. https://doi.org/10.1073/pnas.0812817106

Crown, P.L. \& W.H. WiLls. 2003. Modifying pottery and kivas at Chaco: pentimento, restoration, or renewal? American Antiquity 68: 511-32. https://doi.org/10.2307/3557106

Dutton, B.P. 1937. Leyit Kin, a small house ruin, Chaco Canyon, New Mexico. Unpublished MA

(C) Antiquity Publications Ltd, 2018 dissertation, University of New Mexico, Albuquerque.

HaLl, S.A. 2010. New interpretations of alluvial and paleo-vegetation records from Chaco Canyon, New Mexico, in J.E. Fasselt, K.E. Zeigler \& V. W. Lueth (ed.) Geology of the Four Corners, New Mexico. New Mexico Geological Society Guidebook, $61^{\text {st }}$ Field Conference: 231-46. Socorro: New Mexico Geological Society.

Heitman, C.C. \& S. Plog (ed.). 2015. Chaco revisited: new research on the prehistory of Chaco Canyon, New Mexico. Tucson: University of Arizona Press.

Judd, N.M. 1924. Two Chaco Canyon pit houses (Annual Report of the Board of Regents of the Smithsonian Institution 1922). Washington, D.C.: Government Printing Office.

- 1954. The material culture of Pueblo Bonito (Smithsonian Miscellaneous Collections 124). Washington, D.C.: Smithsonian Institution.

- 1964. The architecture of Pueblo Bonito (Smithsonian Miscellaneous Collections 147(1)). Washington, D.C.: Smithsonian Institution.

Kantner, J. 2012. The Early Pueblo Period: a synthesis of sorts, in R.H. Wilshusen, G. Schachner \& J.R. Allison (ed.) Crucible of the Pueblos: the Early Pueblo Period in the northern Southwest (Monograph 71): 223-61. Los Angeles (CA): Cotsen Institute of Archaeology.

KLUCKнонn, C. 1939. A note on the structures of the refuse mound, in C. Kluckhohn \& P. Reiter (ed.) Preliminary report on the 1937 excavations, Bc50-51, Chaco Canyon, New Mexico (University of New Mexico Bulletin 345, Anthropological Series 3(2)): 26-29. Albuquerque: University of New Mexico Press.

Lekson, S. 1984. Great Pueblo architecture of Chaco Canyon, New Mexico (Publications in Archeology 18B, Chaco Canyon Studies). Albuquerque (NM): National Park Service, Department of the Interior. 


\section{The complex history of Pueblo Bonito and its interpretation}

- 2006. The archaeology of Chaco Canyon: an eleventh century Pueblo regional center. Santa Fe (NM): SAR.

- 2007. The architecture of Chaco Canyon, New Mexico. Salt Lake City: The University of Utah Press.

Marden, K. 2011. Taphonomy, paleopathology and mortuary variability in Chaco Canyon: using bioarchaeological and forensic methods to understand ancient cultural practices. Unpublished $\mathrm{PhD}$ dissertation, Tulane University.

McKenna, P. \& M. Truell. 1986. Small site architecture of Chaco Canyon, New Mexico (Publications in Archeology 18D, Chaco Canyon Studies). Santa Fe (NM): National Park Service.

Mills, B.J. 2002. Recent research on Chaco: changing views on economy, ritual and society. Journal of Archaeological Research 10: 65-117. https://doi.org/10.1023/A:1014564624013

- 2008. Remembering while forgetting: depositional practices and social memory at Chaco, in B.J. Mills \& W.H. Walker (ed.) Memory work: archaeologies of material practices: 81-108. Santa $\mathrm{Fe}(\mathrm{NM})$ : SAR.

Mills, B.J. \& T.J. Ferguson. 2008. Animate objects: shell trumpets and ritual networks in the Greater Southwest. Journal of Archaeological Method and Theory 15: 338-61. https://doi.org/10.1007/s10816-008-9057-5

Mills, B.J., M.A. Peeples, L.D. Aragon, B.A. Bellorado, J.J. Clark, E. Giomi \& T.C. WINDES. 2018. Evaluating Chaco migration scenarios using dynamic social network analysis. Antiquity 92: 922-39.

MOOREHEAD, W.K. 1906. A narrative of explorations in New Mexico, Arizona, Indian, etc.

(Department of Archaeology, Phillips Academy, Bulletin 3). Andover (MA): The Andover Press.

Neitzel, J. (ed.). 2003. Pueblo Bonito: center of the Chacoan world. Washington, D.C.: Smithsonian Institution.

- 2007. Architectural studies of Pueblo Bonito: the past, the present, and the future, in S. Lekson (ed.) The architecture of Chaco Canyon, New Mexico: $127-54$. Salt Lake City: The University of Utah Press.

Pepper, G.H. 1909. The exploration of a burial room in Pueblo Bonito, New Mexico, in His Friends and Associates (ed.) Putnam anniversary volume anthropological essays: 196-252. New York: G.E. Stechert \& Co.
- 1920. Pueblo Bonito (Anthropological Papers of the American Museum of Natural History 27). New York: Order of Trustees.

Price, T.D., S. Plog, S.A. Leblanc \& J.

Krigbaum. 2017. Great house origins and population stability at Pueblo Bonito, Chaco Canyon, New Mexico: the isotopic evidence. Journal of Archaeological Science: Reports 11: 261-73. https://doi.org/10.1016/j.jasrep.2016.11.043

Reimer, P.J., E. Bard, A. Bayliss, J.W. Beck, P.G. Blackwell, C. Bronk Ramsey, C.E. Buck, H. Cheng, R.L. Edwards, M. Friedrich, P.M. Grootes, T.P. Guilderson, H. Haflidason, I. Hajdas, C. Hatté, T.J. Heaton, D.L. Hoffmann, A.G. Hogg, K.A. Hughen, K.F. Kaiser, B. Kromer, S.W. Manning, M. Niu, R.W. Reimer, D.A. Richards, E.M. Scott, J. R. Southon, R.A. Staff, C.S.M. Turney \& J. van der Plicht. 2013. IntCal13 and Marine13 radiocarbon age calibration curves $0-50,000$ years cal BP. Radiocarbon 55: 1869-87. http://dx.doi.org/10.2458/azu_js_rc.55. 16947

Sмith, S. Forthcoming. Pollen analysis of Room 28, Pueblo Bonito, in P.L. Crown (ed.) The house of the cylinder jars: Room 28 in Pueblo Bonito, Chaco Canyon. Manuscript in preparation.

Stein, J.R., D. Ford \& R. Friedman. 2003. Reconstructing Pueblo Bonito, in J.E. Neitzel (ed.) Pueblo Bonito: center of the Chacoan World: 33-60. Washington, D.C.: Smithsonian Institution.

Sturm, J. \& P.L. Crown. 2015. Micro-scale mapping using ground penetrating radar: an example from Room 28, Pueblo Bonito, Chaco Canyon, New Mexico. Advances in Archaeological Practice 3: 125-35.

Vivian, G.R. 1940. Stabilization of Pueblo Bonito, Chaco Canyon National Monument, fiscal year 1940. Report on file, Chaco Culture National Historical Park Archive, University of New Mexico, Albuquerque.

VIVIAN, R.G. 1990. The Chacoan prehistory of the San Juan Basin. New York: Academic Press.

Wills, W.H. 2009. Cultural identity and the archaeological construction of historical narratives: an example from Chaco Canyon. Journal of Archaeological Method and Theory 16: 283-319. https://doi.org/10.1007/s10816-009-9064-1 
Wills, W.H. \& T.C. Windes. 1989. Evidence for population aggregation and dispersal during the Basketmaker III Period in Chaco Canyon, New Mexico. American Antiquity 54: 347-69. https://doi.org/10.2307/281711

Wills, W.H., F.S. Worman, W. Dorshow \& H. Richards-Rissetto. 2012. Shabik'eschee Village in Chaco Canyon: beyond the archetype. American Antiquity 77: 326-50. https://doi.org/10.7183/0002-7316.77. 2.326

Wills, W.H., D.W. Love, S.J. Smith, K.R. Adams, M. Palacios-Fest, W.B. Dorshow, B. Murphy, J.O. Sturm, H. Mattson \& P.L. Crown. 2016. Water management at Pueblo Bonito: evidence from the National Geographic Society trenches. American Antiquity 81: 449-70. https://doi.org/10.1017/S0002731600003942

Wilshusen, R.H. \& R.M. Van Dyke. 2006. Chaco's beginnings: the collapse of Pueblo I villages and the origins of the Chaco System, in S.H. Lekson (ed.) The archaeology of Chaco Canyon, an eleventh-century Pueblo regional center: 221-59. Santa Fe (NM): SAR.

Windes, T.C. 1984. A new look at population in Chaco Canyon, in W.J. Judge \& J.D. Schelberg (ed.) Recent research on Chaco prehistory (Reports of the Chaco Center 8, Division of Cultural Research): 75-87. Albuquerque (NM): National Park Service, U.S. Department of the Interior.
- 1993. The Spadefoot Toad site: investigations at 29SJ 629, Chaco Canyon, New Mexico: artifactual and biological analyses volume II. Santa Fe (NM): National Park Service, U.S. Department of the Interior.

- 2003. This old house: construction and abandonment at Pueblo Bonito, in J. Neitzel (ed.) Pueblo Bonito: center of the Chacoan world: 14-32. Washington, D.C.: Smithsonian Institution.

- 2014. Early Puebloan occupations in the Chaco Region, volume I: excavations and Survey of Basketmaker III and Pueblo I sites, Chaco Canyon, New Mexico (Arizona State Museum Archaeological Series 210). Tucson: Arizona State Museum, University of Arizona.

Windes, T. \& D. Ford. 1992. The nature of the Early Bonito Phase, in D. Doyel (ed.) Anasazi regional organization and the Chaco system: 75-86. (Maxwell Museum of Anthropology Anthropological Paper 5). Albuquerque: University of New Mexico.

- 1996. The Chaco Wood Project: the chronometric reappraisal of Pueblo Bonito. American Antiquity 61: 295-310. https://doi.org/10.2307/282427

Windes, T. \& R.M. Van Dyke. 2012. Pueblo I settlement in the Greater Chaco Basin, in R.H. Wilshusen, G. Schachner \& J.R. Allison (ed.) Crucible of the Pueblos: the Early Pueblo Period in the northern Southwest (Monograph 71): 72-100. Los Angeles (CA): Cotsen Institute of Archaeology.

Received: 14 September 2017; Revised: 6 March 2018; Accepted: 13 March 2018

(C) Antiquity Publications Ltd, 2018 